\title{
Yrittäjyyteen vaikuttavat tekijät - empiirinen tutkimus Etelä-Pohjanmaan maitotiloilla
}

\author{
Eetu Aro, Seppo Vehkamäki ${ }^{1)}$, Matti Ylätalo ${ }^{1)}$ \\ ${ }^{1)}$ Helsingin yliopisto, Taloustieteen laitos, PL 27, 00014 Helsingin yliopisto \\ eetu.aro@ netikka.fi, seppo.vehkamaki@helsinki.fi, matti.ylatalo@helsinki.fi
}

\section{Tiivistelmä}

Artikkelin tavoitteena oli analysoida, miten yrittäjyys ilmenee maidontuotantotiloilla ja millaisia erilaisia yrittäjyystypologioita niiltä löytyy. Päätavoitteena oli tarkastella maatilayrittäjien yrittäjyysmotivaatiota ja siihen vaikuttavia tekijöitä. Lisäksi haluttiin selvittää maatilayrittäjien keskeisiä arvoja, asenteita ja tavoitteita. Tarkastelunäkökulma on ensi sijassa taloustieteellinen, mutta yrittäjyyttä tarkasteltiin myös käyttäytymistieteellisessä ja sosiologisessa kontekstissä.

Artikkelin kohderyhmänä olivat Etelä-Pohjanmaan maitotilat. Tutkimusote on kvantitatiivinen ja eksploratiivinen. Tutkimusaineisto hankittiin postikyselynä ja tilojen valinta suoritettiin satunnaisotantana. Kyselylomake käsitti yhteensä 100 kysymystä, joiden avulla pyrittiin kartoittamaan yrittäjien ominaisuudet, keskeiset yritystoimintaa, maatilan elinkaaren vaihetta ja tilanpidon jatkuvuutta kuvaavat muuttujat. Lopullisessa aineistossa oli 191 tilaa vastausprosentin ollessa 50. Aineiston analysoinnissa käytettiin pääasiallisesti faktori- ja ryhmittelyanalyysiä.

Tuottajien yrittäjyysmotivaatio vaihteli, mutta suurimmalla osalla se oli kohtalaisen hyvä. Nuorilla yrittäjyysmotivaatiota vahvistivat etenkin onnistuminen työssä ja hyvä taloudellinen tulos. Vanhoilla viljelijöillä yrittäjyysmotivaatiota vahvisti etenkin tieto maatilan jatkajasta. Motivaatiota lisäsivät karjaan liittyvät seikat, kuten karjan hyvä terveystilanne sekä maidon hyvä tuotos ja laatu. Yrittäjyysmotivaatiota heikensivät taas ulkoiset tekijät, etenkin maatalouden yleinen epävarmuus ja maidon hinnan lasku. Vanhoilla yrittäjillä motivaatiota heikensivät sisäiset tekijät, kuten epävarmuus jatkajasta ja oman terveyden heikentyminen.

Maidontuottajien jaottelemiseksi erilaisiin yrittäjyystypologioihin käytettiin faktorianalyysin tuloksiin perustuvaa ryhmittelyanalyysiä, jonka perusteella maidontuottajat jaoteltiin neljään ryhmään. Ensimmäisen ryhmän yrittäjillä oli hyvä ammatillinen koulutus. Heille tärkeitä asioita olivat tuottavuus, tilakoon kasvu ja karjaan liittyvät haasteet. Heidän tavoitteissaan korostuivat maidon hyvä laatu, eläinten hyvinvointi, työn mielekkyyden parantaminen sekä kannattavuuden parantamisen ohella myös elämän laadun parantaminen. Toisen ryhmän yrittäjät olivat iäkkäitä ja heidän ammatillinen koulutuksensa oli alhainen. Tilakoko oli pieni. Toisen ryhmän yrittäjät aikoivat investoida vähän lähitulevaisuudessa ja tilan toiminnan jatkuvuus oli epävarmempaa kuin muilla ryhmillä. Heille olivat tärkeitä sisäinen tehokkuus, sosiaalinen arvostus, turvattu ja itsenäinen työ sekä karjatalouteen liittyvät haasteet. Kolmannen ryhmän yrittäjillä oli hyvä ammatillinen koulutus. Heidän keskimääräinen peltoalansa oli suurin ja maidon keskituotos alhaisin verrattuna muihin ryhmiin. Tuotantosuunnan vaihtajia oli suhteellisesti eniten tässä ryhmässä. Tämän ryhmän yrittäjille oli tärkeää tuotannon tehostaminen, tilakoon kasvu sekä maatilan jatkuvuus. Heillä korostuivat taloudelliset tavoitteet. Neljännen ryhmän yrittäjillä oli alhainen ammatillinen koulutus. Ryhmässä oli voimakkaasti tuotantoaan laajentavia yrittäjiä suhteellisesti eniten ja tuotantosuunnan vaihtajia vähiten muihin ryhmiin verrattuna. Heille tärkeitä asioita olivat tuottavuus, turvattu työ sekä varovaisuus. Neljännen ryhmän yrittäjien tavoitteissa korostuivat taloudelliset tavoitteet ja tilan kokonaisvaltainen kehittäminen. Neljännen ryhmän yrittäjät suhtautuivat myönteisimmin maatalouden rakennekehitykseen.

Asiasanat: yrittäjyys, maatilayrittäjä, maidontuotanto, faktorianalyysi, ryhmittelyanalyysi 


\title{
Yrittäjyyteen vaikuttavat tekijät - empiirinen tutkimus Etelä-Pohjanmaan maitotiloilla
}

\author{
Eetu Aro, Seppo Vehkamäki ${ }^{1)}$, Matti Ylätalo ${ }^{1)}$ \\ ${ }^{1)}$ Helsingin yliopisto, Taloustieteen laitos, PL 27, 00014 Helsingin yliopisto \\ eetu.aro@netikka.fi,seppo.vehkamaki@helsinki.fi,matti.ylatalo@helsinki.fi
}

\section{Johdanto}

Yrittäjyys on ajattelu-, toiminta- ja suhtautumistapa. Se ilmenee ihmisen uskomuksissa, teoissa ja tunneilmaisuissa. Yrittäjyys liittyy toimintaan, jolla on tavoitteet (Peltonen 1986). Vakiintuneen käsityksen mukaan yrittäjyys on yksilön ominaisuus, joka usein on sidoksissa ympäröivän yhteisön arvoihin. Yritys on siten määritelmällisesti yrittävän ihmisen toiminnan tulos, jolloin yrityksen aktiviteetit riippuvat yrittävistä henkilöistä. Yrittäjyyden tuntomerkkinä pidetään vahvaa yritykseen sitoutumista, mikä synnyttää taloudellista epävarmuutta. Omistajayrittäjä on taloudellisesti sitoutunut yritykseen ja toimii riskinkantajana (Kupiainen ym. 2000).

Yrittäjyys on maatalousyrittäjälle tärkeä ominaisuus. Hän joutuu sopeutumaan muuttuvaan toimintaympäristöön, minkä vuoksi maatalousyrittäjä joutuu jatkuvasti pohtimaan maatilansa tavoitteita, kehittämistä ja jatkuvuutta. Maatalousyrittäjien on tärkeää taloudellisessa mielessä mukauttaa yritystoimintansa vastaamaan toimintaympäristön muutoksia, jos tuotantopanosten ja tuotteiden hinnoissa tai tuissa tapahtuu muutoksia. Myös arvot ja asenteet yrittäjyyttä kohtaan muuttuvat (esim. Sipiläinen ym. 1998, Timonen 2000). Koska entistä suurempi osuus maatalouden tuloista on peräisin suorista tulotuista eikä enää riipu yrittäjän työpanoksen ja oman pääoman käytön tuloksesta, tämän pelätään heikentävän motivaatiota yrittämiseen erityisesti työvaltaisilla kotieläintiloilla. Toisaalta toimintaympäristön muutos pakottaa kehittämään ja monipuolistamaan tuotantotoimintaa sekä luomaan uusia toimintastrategioita. Tällaisissa muutostilanteissa maatalousyrittäjä joutuu arvoimaan yrittäjyyttään, yrittäjyysmotivaatiotaan, yrityksensä tavoitteita sekä etsimään työlleen uusia merkityksiä ja perusteita.

Artikkelin tavoitteena on yrittäjyyteen vaikuttavien tekijöiden analysointi Etelä-Pohjanmaan maidontuotantotiloilla. Yrittäjyyttä tarkastellaan myös yrittäjyysmotivaation ja maatilayrittäjän arvojen ja asenteiden näkökulmasta. Lähtökohtana on, että yrittäjyyteen vaikuttavat hyvin moninaiset tekijät ja että ne ovat hyvin yksilöllisiä. Artikkelin tavoitteena on vastata seuraaviin kysymyksiin:

1. Miten maatilayrittäjyys ilmenee Etelä-Pohjanmaalla?

2. Millainen on maidontuottajan yrittäjyysmotivaatio ja mitkä ovat siihen vaikuttavat tekijät?

3. Mitkä ovat maidontuottajan keskeisimmät arvot yrittäjänä, asenteet yrittäjyyttä kohtaan ja tavoitteet yrittäjänä?

\begin{abstract}
Aineisto ja menetelmät
Artikkelin kohderyhmänä ovat Etelä-Pohjanmaan maitotilat. Tutkimusote on kvantitatiivinen ja eksploratiivinen. Tutkimusaineisto hankittiin postikyselynä ja tilojen valinta suoritettiin satunnaisotantana Maatalouden laskentakeskuksen tilarekisteristä. Kyselylomakkeella kysyttiin erilaisilla muuttujilla yrittäjän työn arvostusta, yrittäjyysmotivaatiota, tavoitteita sekä itsensä nimeämistä yrittäjänä. Postikysely suoritettiin Etelä-Pohjanmaan Pro Agria Maaseutukeskuksen kautta. Lopullinen tilojen lukumäärä oli 191 tilaa ja vastausprosentti 50.

Vastanneista maatilayrittäjistä $75 \%$ oli miehiä ja $25 \%$ naisia. Yrittäjien keski-ikä vastaushetkellä oli 45,1 vuotta. Vastanneita maatilayrittäjiä oli jokaisesta kunnasta Etelä-Pohjanmaan alueelta. Maatilojen kokonaispeltopinta-ala oli keskimäärin 48,65 ha. Vuokramaata tiloilla oli keskimäärin 20,76 ha. Lehmien lukumäärä oli keskimäärin 25 lehmää ja maidon keskituotos 7757 kiloa. Yrittäjistä $23 \%$ harjoitti sivuelinkeinoja. Maatiloista $75 \%$ osallistui karjantarkkailuun. Maatilayrityksistä $76 \%$ jatkoi tuotantoaan nykyisellään, $9 \%$ :lla tuotannon jatkaminen oli epävarmaa ja $14 \%$ aikoi lopettaa maidontuotannon lähivuosina. Tuotantosuuntaa aikoi vaihtaa $9 \%$ maatilayrityksistä, joka oli $67 \%$ lopettavista tiloista. Tiloista $8 \%$ aikoi laajentaa tuotantoaan voimakkaasti.

Aineiston tilastollinen analyysi suoritettiin SPSS 12.0.1 for Windows -ohjelmistolla. Kvantitatiivisen aineiston analysoinnissa käytettiin monimuuttujamenetelmistä faktori-, pääkomponentti- ja
\end{abstract}


ryhmittelyanalyysia. Tilastollisissa testauksissa käytettiin varianssi- ja korrelaatioanalyysia. Varianssianalyysi edellyttää muuttujien osalta jakaumien normaalisuutta ja ryhmien varianssien yhtäsuuruutta. Kun ryhmien varianssit olivat erisuuria ja kun analysoitiin luokka- ja järjestysasteikollisia mittauksia, käytettiin ei-parametrisiä testejä.

\section{Tutkimustulokset}

Työn arvostuksen faktorianalyysissa tulokseksi saatiin neljän faktorin ratkaisu. Faktorit olivat turvattu työ, itsenäinen työ, sosiaalinen arvostus sekä sosiaalinen vaikuttaminen. Mitä alhaisempi koulutus yrittäjällä oli, sitä tärkeämpää hänelle oli turvattu työ verrattuna korkeammin koulutetuille yrittäjille. Sama tilanne oli sekä yleissivistävän että ammatillisen koulutuksen suhteen. Turvattu työ oli yrittäjälle sitä tärkeämpää, mitä kauemmin tila oli ollut yrittäjän hallussa. Itsenäisen työn arvostus oli sitä suurempi, mitä nuorempi yrittäjä oli ja samalla mitä parempi oli yrittäjän ammatillinen koulutus. Sekä sosiaalinen arvostus että sosiaalinen vaikuttaminen olivat tärkeämpiä yrittäjille, joiden tilat osallistuivat karjantarkkailuun kuin yrittäjille, joiden tilat eivät kuuluneet karjantarkkailuun. Sivuelin-keinoa harjoittamattomille yrittäjille sosiaalisen arvostuksen merkitys oli tärkeämpi kuin sivuelinkeinoa harjoittaville yrittäjille.

Yrittäjyysmotivaation faktorianalyysissa tulokseksi saatiin neljän faktorin ratkaisu. Faktorit olivat aineellinen motivaatio, yrittäjämotivaatio, ulkoinen tuki sekä jatkuvuus. Vanhoille yrittäjille jatkuvuuden merkitys oli tärkeämpää verrattuna nuoriin yrittäjiin. Aineellinen motivaatio ja jatkuvuus olivat tärkeämpiä tiloille, joilla oli varma jatkaja kuin tiloille, joilla ei ollut jatkajaa. Jatkuvuus oli myös tärkeämpää tiloilla, joilla sukupolvenvaihdos oli ajankohtainen kuin tiloille, joilla sukupolvenvaihdos ei ollut ajankohtainen kysymys. Mitä parempi yrittäjän koulutus oli, sitä tärkeämpää hänelle oli aineellinen motivaatio. Jatkuvuus puolestaan oli sitä tärkeämpää mitä alhaisempi oli yrittäjän koulutus.

Tilakoko oli yhteydessä aineelliseen motivaatioon. Mitä suurempi tila oli kooltaan, sitä tärkeämpää yrittäjälle oli aineellinen motivaatio. Yrittäjämotivaatio oli suurempi yrittäjillä, joiden tilat kuuluivat karjantarkkailuun kuin karjantarkkailuun kuulumattomilla yrittäjillä. Yrittäjämotivaatio oli alhaisin yrittäjillä, joiden lehmien maidon keskituotos oli alle $6500 \mathrm{~kg}$.

Yrittäjien tavoitteiden analyysissa saatiin tulokseksi viisi ulottuvuutta, jotka ovat suurimittakaavainen tuotanto, tuotannon tehostaminen, tuotannon kehittäminen, karjan kehittäminen sekä varovaisuus. Mitä nuorempi yrittäjä oli, sitä tärkeämpää hänelle oli sekä tuotannon että karjan kehittäminen. Mitä enemmän yrittäjällä oli kokemusta tilanpidosta, sitä tärkeämpää hänelle oli tuotannon tehostaminen. Suurimittakaavainen tuotanto oli tärkeämpi niiden tilojen yrittäjille, joilla oli varma jatkaja kuin yrittäjille, joilla ei ollut jatkajaa tiedossa. Suurimittakaavainen tuotanto oli sitä tärkeämpää, mitä parempi oli yrittäjän ammatillinen koulutus.

Mitä suurempi tila oli kooltaan, sitä tärkeämpää yrittäjille oli suurimittakaavaisen tuotannon tavoitteet. Myös tuotannon kehittämisen tavoitteet tulivat tärkeämmiksi tilan peltopinta-alan kasvaessa. Mitä korkeampi maidon keskituotos oli, sitä tärkeämpää yrittäjille olivat karjan kehittämiseen liittyvät tavoitteet. Karjantarkkailuun osallistuvien tilojen yrittäjille karjan kehittäminen oli tärkeämpää kuin karjantarkkailuun osallistumattomien tilojen yrittäjille. Suurimittakaavainen tuotanto oli tärkeämpää yrittäjille, jotka harjoittivat sivuelinkeinoja kuin yrittäjille, jotka eivät harjoittaneet sivuelinkeinoja.

Yrittäjien ryhmittelemiseksi eri yrittäjäluokkiin eli typologioihin suoritettiin faktori-analyysi työn arvostuksen, yrittäjyysmotivaation ja yrittäjän tavoitteiden muuttujia käyttäen. Faktorianalyysin tulokseksi saatiin kymmenen faktorin ratkaisu. Faktorit olivat sisäinen tehokkuus, turvattu työ, tuottavuus, tuotannon tehostaminen, sosiaalinen arvostus, jatkuvuus, kasvu, itsenäinen työ, ulkoinen tuki sekä varovaisuus. Ryhmittelyanalyysissä päädyttiin neljän ryhmän ratkaisuun.

Suurin osa ensimmäisen ryhmän yrittäjistä oli 30-59 -vuotiaita. Heillä oli hyvä amma-tillinen koulutus. Yrittäjillä oli suurin keskimääräinen lehmien lukumäärä ja maidon keskituotos sekä pienin tilan hallinta-aika verrattuna muihin ryhmiin. Ensimmäisen ryhmän yrittäjille oli tärkeää tuottavuus ja tilakoon kasvu.

Toisen ryhmän yrittäjien ikä ja tilan hallinta-aika olivat korkeita. Heidän ammatillinen koulutuksensa oli alhainen. Myös tilakoko oli pieni. Toisen ryhmän yrittäjät aikoivat investoida lähitulevaisuudessa verrattain vähän ja jatkuvuus oli epävarmempaa kuin muilla ryhmillä. Myös sivuelinkeinojen harjoittajia oli suhteellisesti vähiten toisessa ryhmässä. Heille oli tärkeää sisäinen tehokkuus, turvattu 
ja itsenäinen työ sekä sosiaalinen arvostus. Tilakoon kasvattaminen ei ollut keskeinen tavoite toisen ryhmän yrittäjille.

Kolmannen ryhmän yrittäjillä oli hyvä ammatillinen koulutus. Ryhmä oli keskimääräisen peltopinta-alan suhteen suurin verrattuna muihin ryhmiin, mutta lehmien keskituotos oli alhaisin. Ryhmään kuului kuitenkin hyvin erikoisia tiloja sekä eri-ikäisiä yrittäjiä. Tuotantosuunnan vaihtajia oli suhteellisesti eniten kolmannessa ryhmässä kuin muissa ryhmissä. Kolmannen ryhmän yrittäjille oli tärkeää tuotannon tehostaminen, tilakoon kasvu sekä maatilan jatkuvuus.

Neljäs ryhmä oli lukumäärältään huomattavasti suurempi kuin muut ryhmät. Neljän-nessä ryhmässä oli mukana kaikenkokoisia tiloja ja sen yrittäjien ikäjakauma oli suuri. Yrittäjillä oli alhainen ammatillinen koulutus. Voimakkaasti tuotantoaan laajentavia yrittäjiä oli neljännessä ryhmässä eniten ja tuotantosuunnan vaihtajia vähiten verrattuna muihin ryhmiin. Neljännessä ryhmässä korostuivat tuottavuuden kohottaminen, tilan kehittäminen sekä varovaisuus.

\section{Johtopäätökset}

Tässä artikkelissa teoreettinen näkökulma yrittäjyyteen oli integroiva eli siinä käytettiin hyväksi erilaisia yrittäjyyden lähestymistapoja, jotka täydensivät toisiaan. Yrittäjyyttä tarkasteltiin erityisesti käyttäytymistieteellisessä ja sosiologisessa kontekstissa taloudelliseen näkökulmaan liitettynä. Persoonallisuus- ja piirreteoriat soveltuivat tässä yhteydessä huonosti selittämään yrittäjyyttä ja yrittäjän käyttäytymistä tutkimusmetodologisista syistä ja tavoitteista johtuen. Myös yrittäjyyden koulukunnat soveltuivat huonosti tulkitsemaan tämän artikkelin tuloksia, koska ne lähestyvät yrittäjyyttä omista tiukasti rajatuista lähtökohdistaan.

Taloustieteellisen näkökulman perusteella markkinat ja harjoitettu maatalouspolitiikka säätelivät voimakkaasti yrittäjän mahdollisuuksia esimerkiksi tilan toiminnan kehittämisen ja tuotannon laajentamisen kannalta. Investointituet kannustivat yrittäjiä laajentamaan ja kehittämään tilansa toimintaa. Raha ja yritystoiminnasta saatu tulos kannustivat monella tapaa yrittäjää. Taloudelliset seikat olivat aina vahvasti mukana yrittäjien päätöksenteossa. Voiton tai hyödyn maksimointi ei pystynyt kuitenkaan selittämään aina yrittäjän toimintaa yrittäjyyden näkökulmasta. Varsinkin yrittäjäksi ryhtymisen taustalla oli moninaisia seikkoja, mutta kuitenkin ne liittyivät usein ansaitsemisen mahdollisuuteen ja itsenäisen työn motiiville. Tulosten perusteella oli havaittavissa hyvin erilaisia yrittäjätyyppejä tavoitteiden suhteen. Voiton ja hyödyn maksimointi oli kuitenkin vahva taustavoima maidontuottajien taloudelliselle käyttäytymiselle.

Yrittäjyyden sosiologisesta näkökulmasta katsottuna yrittäjillä oli vahvoja ammatillisia arvoja, joita yrittäjät olivat oppineet vanhemmiltaan. Yrittäjän saama amma-tillinen koulutus osaltaan ohjasi arvojen omaksumisen prosessia eli sosialisaatiota. Tähän sosialisaatioon vaikutti myös yrittäjän aikaisempi työkokemus ennen yrittäjänä toimimista. Tulokset antoivat viitteitä myös siitä, että ympäröivä maaseutuyhteisö vaikutti taustalla yrittäjän sosialisaation prosessiin. Tästä kertoivat kyläyhteisöjen erilaisuus ja pienien yrityskeskittymien syntyminen. Tämän sosialisaation lopputuloksena yrittäjälle muodostui omanlaisensa yrittäjyysideologia, joka ohjasi yrittäjän tapaa nähdä ympäröivä todellisuus ja reagoida sekä sopeutua esimerkiksi yrityksen toimintaympäristön muutoksiin. Yrittäjän menestymistä yrittäjänä ei voitu sosiologisesta näkökulmasta selittää kovinkaan luotettavasti tässä tutkimuksessa. Tulokset kuitenkin osoittivat, että yrittäjien arvot ja asenteet vaihtelivat yrittäjyysideologian suhteen merkittävästikin toisistaan, joiden perusteella yrittäjiä voitiin luokitella erilaisiin ryhmiin.

Yrittäjyyden psykologisesta näkökulmasta huomioituna arvojen yhteys yrittäjyyteen todettiin jo edellä, mikä oli lähellä myös sosiaalipsykologista näkökulmaa. Psykologisesta näkökulmasta voitiin tulosten perusteella havaita yrittäjämotivaation erilaiset ilmenemistavat ja motiivit. Vahvoja tunnemotiiveja yrittäjillä olivat itsenäisyys toimia yrittäjänä ja tehdä omat päätökset sekä saavuttaa konkreettisia tuloksia ja tavoitteita, kuten maidon laadun pitäminen hyvänä, jalostuksen kautta saavutetut tulokset tai investointien toteuttaminen ja loppuunsaattaminen. Yrittäjien kehitysmotiivit liittyivät tilan kokonaisvaltaiseen kehittämiseen, tuotannon suunnitteluun ja laajentamiseen sekä tuotannon tehostamiseen ja koneellistamiseen yrittäjän omia ideoita käyttämällä. Yrittäjien välinemotiivit liittyivät tavoitteisiin pääsemiseksi kuten esimerkiksi talouden suunnittelu investointien tekemiseksi, maksuvalmiuden säilyttämiseksi, kannattavuuden parantamiseksi sekä velkojen poismaksamiseksi. 


\section{Kirjallisuus}

Aro, E. 2005. Yrittäjyyteen vaikuttavat tekijät - empiirinen tutkimus Etelä - Pohjanmaan maidontuotantotiloilla. Helsingin yliopiston Taloustieteen laitoksen pro-gradutyö. 98 s. + liitteet.

Kupiainen, T., Helenius, J., Kaihola, O. \& Hyvönen, S. 2000. Maaseudun pienyrityksen menestyminen. Maatalouden taloudellinen tutkimuslaitoksen julkaisuja 239. 128 s. Vammala.

Peltonen, M. 1986. Yrittäjyys. 240 s. Keuruu.

Sipiläinen, T., Ryhänen, M., Ylätalo, M. \& Laineenoja, J. 1998. Maidontuottajien yrittäjyysmotivaatio ja -asenteet. Julkaisussa: Ryhänen, M., Sipiläinen, T. \& Ylätalo, M. (toim.) 1998. Maatilojen tuotanto ja talous Vieremän kunnassa vuosina 1985-2000. s.109 -147. Helsingin yliopiston Taloustieteen laitoksen julk. No 21:1 - 227.

Timonen, R. 2000. Yrittävyys, liikkeenjohto ja menestyminen maatilayrityksissä. Summary: Entrepreneurship, Management and Success in Farm Businesses. Väitösk. Helsingin yliopiston Taloustieteen laitoksen julk. 28:1234. 